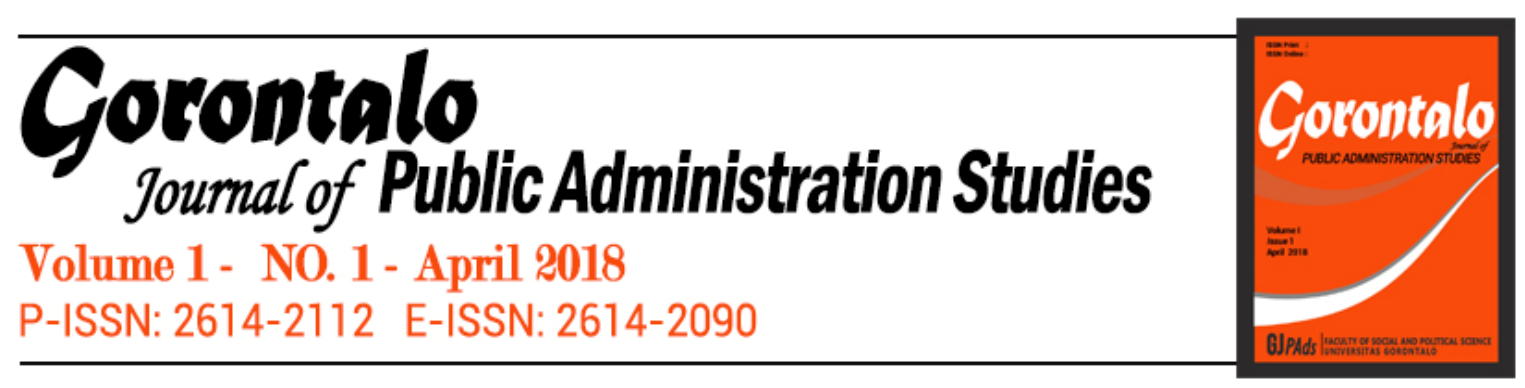

\title{
Peningkatan Kualitas Perangkat Desa Guna Pemantapan Pelaksanaan Pembangunan di Desa Ilotidea Kabupaten Gorontalo
}

Nirmala A. Sahi

Program Studi Administrasi Publik Universitas Gorontalo Nirmala_apriyanti@yahoo.com

\begin{abstract}
This study aims to determine the improvement of the quality of village apparatus in order to strengthen the implementation of development in Ilotidea Village, Tilango District, Gorontalo Regency. The research method used qualitative descriptive method. Data obtained through interviews, observation and documentation. The sample used in this study were 25 respondents from the total population of 50 respondents. The results of the research show several findings are: First, the quality of village apparatus is still not optimal or still very need to be improved. Secondly, the ability, willingness and potential of the village apparatus and the impacts and approaches of governance and the implementation of development have not been maximized because human resources are still limited.
\end{abstract}

Keywords: development; village aparatus; Gorontalo Regency.

\begin{abstract}
ABSTRAK
Penelitian ini bertujuan untuk mengetahui peningkatan kualitas aparatur desa dalam rangka memperkuat pelaksanaan pembangunan di Desa Ilotidea, Kecamatan Tilango, Kabupaten Gorontalo. Metode penelitian menggunakan metode deskriptif kualitatif. Data diperoleh melalui wawancara, observasi dan dokumentasi. Sampel yang digunakan dalam penelitian ini adalah 25 responden dari total populasi 50 responden. Hasil penelitian menunjukkan beberapa temuan yaitu: Pertama, kualitas aparatur desa masih belum optimal atau masih sangat perlu ditingkatkan. Kedua, kemampuan, kemauan dan potensi aparatur desa serta dampak dan pendekatan tata kelola dan pelaksanaan pembangunan belum dimaksimalkan karena sumber daya manusia masih terbatas.
\end{abstract}

Kata Kunci: pembangunan; perangkat desa; Kabupaten Gorontalo.

\section{PENDAHULUAN}

Pemerintahan desa dan wadah kemasyarakatan sangat ditentukan oleh adanya faktor manusia sebagai aktor yang punya peranan dalam kegiatan pemerintahan, kemasyarakatan dan pembangunan. Walaupun dengan keanekaragaman letak dan kedudukan serta adat kebiasaan setempat tetapi tidak terlepas dari adanya pola kesatuan dan persatuan sebagai implementasi utuh dari bentuk negara secara konstitusional yaitu suatu negara kesatuan yang berbentuk Republik (Undang-Undang Dasar 1945 Pasal 1 ayat 1). Betapa 
pun kecil dan dimanapun juga kedudukan dan letak dari unit-unit kelompok masyarakat setempat itu (desa), akan tetapi selalu dijangkau, dimonitor dan dipedulikan pelayanan serta perlindungan oleh Pemerintah Republik Indonesia.

Untuk mencapai suatu masyarakat yang adil dan makmur secara merata dan menyeluruh sampai ke desa-desa, merupakan tugas / pekerjaan yang berat tetapi mulia yang harus dilaksanakan oleh pemerintah dan juga oleh seluruh anggota masyarakat. Pada sisi yang lain terasa dan tampak bahwa arus kemajuan dan perubahan-perubahan berpacu laju dengan mekanisme kecanggihan, oleh karena semakin meningkatnya ilmu pengetahuan dan teknologi yang bergerak dari kota-kota sampai ke desa-desa.

Faktor-faktor tersebut bukan hanya dibutuhkan bagi unit-unit pemerintahan atasan saja akan tetapi juga harus melekat pada unit-unit menengah, bahkan sampai pada unit-unit bawahan seperti pada unit pemerintahan terendah di desa. Hal-hal yang esensial, diperlukan sebagai sistem yang utuh, terpadu secara berjenjang dengan posisi dan fungsi masingmasing.

Begitu pentingnya faktor-faktor tersebut diatas mengakibatkan pada unitunit pemerintahan terendah seperti di desa-desa yang terpencil yang jauh dari sentuhan langsung pemerintah pusat, memerlukan kesadaran dan partisipasi organisasi pemerintahan yang ada pada masyarakat hukum adat, maupun oleh organisasi-organisasi kemasyarakatan yang ada di desa, untuk mengantisipasi dan menangani serta menanggulangi tugas yang diakibatkan oleh faktor-faktor tersebut, maka dibutuhkan kualitas aparat pemerintah desa.

Organisasi pemerintah atasan inilah yang memancarkan tugas-tugas dekonsentrasi dan desentralisasi secara operasianal di desa. Manakala mekanisme operasionalnya terkoordinasi dengan baik, maka alur-alur pelaksanaan tugas akan mengalir dan turun terselenggara secara sistematis kedelta organisasi pemerintah desa. Apabila tertata dan tersistem dan terpadu secara baik, maka sudahlah pasti pelaksanaan tugas-tugas operasional akan berjalan lancar dan mudah untuk mencapai sasaran walaupun volume tugas memang bervariasi dan sulit. Akan tetapi jikalau terjadi ketimpangan operasional dari unit-unit lokal ataupun unit-unit sektoral dari atasan, sudahlah tentu akan menimbulkan kendala-kendala dan benturan pelaksanaan yang berdampak kurang efektif dan serasi.

Dalam peningkatan kualitas perangkat desa perlu meningkatkan pengabdian dan kesetiaan para aparatur pemerintah. Berarti bahwa dalam segala tingkatan dan posisi dimana saja pemerintah itu bertugas, perlu mengusahakan peningkatan kualitas serta kemampuan untuk semakin berdaya guna. Pemerintah desa sudah tentu tidak dikecualikan mengingat bahwa desadesa itu merupakan basis-basis dan sendi-sendi Negara Kesatuan Republik Indonesia.

Dalam kerangka tersebut diatas, ditegaskan pula bahwa "usaha memperkuat dan memajukan pemerintahan desa perlu dilanjutkan dan lebih dikembangkan sehingga mampu melayani dan mengayomi masyarakat, menggerakkan partisipasi rakyat dan pembangunan serta menyelenggarakan fungsi pemerintahan desa secara efektif dan efisien. Demikian pula dengan adanya peraturan perundang-undangan lebih memberikan arah dan kepastian peningkatan dan pengembangan pemerintah desa. Mengacu dari latar belakang di atas maka untuk mewujudkannya diperlukan suatu pola dan perilaku 
masyarakat untuk ikut terlibat langsung dan aktif dalam pelaksanaan pembangunan itu sendiri, baik artian pembangunan secara luas dan arti pembangunan secara spesifik.

\section{KAJIAN TEORI}

\subsection{Kualitas dan Peningkatan Kualitas}

Kemudian menurut Pariata Westra dan kawan-kawan dalam Ensiklopedia Administrasi (1981:268) menjelaskan pula : "Kualitas diartikan dengan nilai-nilai atau sifat-sifat yang seharusnya dimiliki oleh diri seseorang atau orang-orang pemimpin, agar ia dapat menjadi pemimpin yang baik". Nilai-nilai tersebut didekati dengan sifat-sifat yang dapat diklasifikasikan atas, vitalitas, intelegensia, humanitas, dam moralitas.

Dari pengertian ini jelas pula bahwa menggunakan istilah kualitas itu seharusnya dilengkapi dengan sifat-sifat tertentu agar menjadi pemimpin yang baik, yaitu vitalitas, intelegensia, humanitas, moralitas dan lain-lain. Jadi apabila kualitas ini tidak dilengkapi dengan sifat-sifat tersebut diatas, maka muncullah hakekat pengertiannya, berarti tidak tepat dan jelas pemakaiannya. Selanjutnya menurut Prof. Drs. A.L. Tampi dalam makalah "Peningkatan kualitas manusia Indonesia" (1983), menjelaskan Kualitas dapat diartikan dengan mutu atau juga dalam bahasa praktis disamakan dengan kata bobot, nilai, dan lain-lain.

Berangkat dari pengertian ini dapat diperjelas lagi dengan hal-hal menyangkut derajat kepandaian, derajat kecerdasan, derajat kemampuan atau kualitas yang dilengkapi dengan vitalitas (keunggulan), kelebihan intelegensi, bertindak humanitas dan dengan bersifat moralis Maka dalam pengertian teknis operasional, adalah mutu dari orang atau orang-orang yang memiliki keahlian, kecerdasan, keterampilan dan berpandangan luas serta berkemauan untuk maju dan berhasil (sukses).

Dengan demikian dapat dikatakan bahwa kualitas manusia itu adalah suatu ukuran tentang derajat profesionalisme, derajat kecerdasan, derajat keterampilan, derajat kemauan dan kemampuan, derajat kebaikan dan kejujuran yang dipergunakan bagi pembangunan manusia Indonesia seutuhnya, yang diimplementasikan sebagai bentuk daya juang, pengabdian dan pengamalan.

Perkataan "Peningkatan Kualitas" adalah dua kata yang dihubungkan dan bermaksud untuk berbuat, menjadikan objeknya untuk mencapai suatu mutu atau derajat yang lebih tinggi, lebih berderajat atau lebih bermutu dan lebih bernilai, lalu boleh menjadi subjek yang lebih berkualitas. Oleh karena sifatnya berbuat, menjadikan untuk mencapai suatu derajat atau mutu yang lebih baik, maka fungsi dua kata ini pun bersifat dinamis, beraktifitas atau bergerak dan berkegiatan.

Gerak kegiatan dilakukan adalah secara sadar, terencana dan tepat arahnya. "Peningkatan kualitas adalah suatu proses kegiatan yang dilakukan secara sadar, terencana yang diarahkan pada suatu obyek (orang dan orangorang) untuk menjadikan agar lebih bermutu, lebih diangkat derajat untuk adanya kesetaraan pada mengantisipasi kebutuhan perkembangan yang semakin luas dan maju.

Dari pengertian-pengertian tersebut diatas, maka dapatlah diangkat beberapa unsur pokok yaitu : 
a. Ada kegiatan yang dilakukan secara sadar dan terencana.

b. Ada yang menerima untuk mendapatkan atau memperoleh berupa bakat, bahan-bahan, pengetahuan, keterampilan agar menjadi lebih cerdas dan terampil.

c. Ada yang memberikan (fasilitator) bahan-bahan pengetahuan sebagai input.

d. Ada sasaran tertentu agar dapat meningkatkan kecerdasan, keahlian dan keterampilan untuk nantinya boleh mengantisipasi dan menyetarakan dengan tuntutan perkembangan serta kemajuan dan sebagainya.

Peningkatan kualitas itu diperlukan setiap waktu dan setiap fase dalam segala bidang usaha kerja apapun juga. Dan faktor peningkatan kualitas ini pada hakekatnya menyangkut seluruh eksistensi manusia, baik fisik maupun psikisnya. Karena pelakunya adalah manusia dalam kelengkapan jasmani dan rohaninya dalam kelengkapan emosi maupun rasionya, sama-sama secara harmonis berjalan, tidak boleh pincang dan berat sebelah.

Adanya peningkatan kualitas itu merupakan keutuhan dan kebulatan agar keseimbangan jasmani dan rohani serta emosi dan rasio harus tumbuh sejajar dalam suatu dinamika yang harmonis. Sasarannya bukan semata-mata hanya bagi dan untuk orang-orang, akan tetapi menyangkut seluruh lingkungan, sumber daya alam dan sumber daya manusia yang jauh berproses dan beradaptasi dengan kemajuan-kemajuan dan kebutuhan-kebutuhan manusia seluruhnya.

\subsection{Desa dan Pemantapan Pembangunan Desa}

Menurut Sutardjo Kartohadikusumo (Tahun 1953 hal 2) dinyatakan bahwa: "Desa ialah suatu kesatuan hukum dimana bertempat tinggal suatu masyarakat yang berkuasa menjadikan pemerintahan sendiri". Sejalan dengan itu, Menurut Bouman (Tahun 1973 : 12), bahwa desa adalah salah satu bentuk kuno dari kehidupan bersama sebanyak beberapa ribu orang saling mengenai, kebanyakan yang termasuk didalamnya hidup dari pertanian, perikanan dan sebagainya usaha-usaha yang dapat dipengaruhi oleh hukum alam dan kehendak alam.

Adapun menurut Undang-Undang No. 32 Tahun 2004 tentang Pemerintahan Daerah (Pasal 1 Ayat 12) Desa adalah kesatuan masyarakat hukum yang memiliki batas-batas wilayah yang berwenang untuk mengatur dan mengurus kepentingan masyarakat setempat, berdasarkan asal-usul dan adat istiadat setempat yang diakui dan dihormati dalam system Pemerintahan Negara Kesatuan Republik Indonesia.

Mempelajari akan pengertian dari Undang-Undang Nomor 32 Tahun 2004 ini, maka pengertian ini merupakan suatu definisi operasional yang menampakkan aspek hukum, aspek sosiologi, aspek administrasi - organisasi, aspek pemerintahan, aspek otonomi dan terikat oleh kepentingan Negara Kesatuan Republik Indonesia. Pada sisi lain menuntut akan pelaksanaan penyelenggaraan tertib administrasi kewilayahan dan pemilihan wilayah desa, tertib kependudukan (administrasi kependudukan) tertib organisasi pemerintahan, tertib hukum dan sebagainya.

Sebagai salah satu definisi operasional menurut Undang-Undang Nomor 32 tahun 2004, maka dari dalamnya dapat ditemukan beberapa unsur operasional yang diangkat dari keseluruhannya ialah :

a. Ada unsur kewilayahan tertentu, ialah adanya wadah dan luasnya wilayah yang harus ada tertib administrasinya dengan ada kejelasan mengenai 
pemilikan dan penggunaannya secara sah. Ada unsur wilayah berarti pula adanya tertib penggunaan dan pengolahan lingkungannya yang boleh lestari kesuburan tanahnya, tidak menjadi tandus dengan mengakibatkan erosi terutama bagi wilayah sumber air agar tidak mengakibatkan kekeringan atau menimbulkan banjir dan lain-lain merupakan struktur tanahnya.

b. Ada unsur penduduk sebagai kesatuan masyarakat termasuk didalamnya kesatuan masyarakat hukum ialah agar ada tertib kependudukan dan tertib ke masyarakat yang tercatat semuanya dalam register penduduk desa dan masyarakat yang mentaati dan memelihara tata krama sopan santun, terikat oleh hubungan sosial dan kemasyarakatan yang mentaati dan menghargakan tata tertib pergaulan serta adat kebiasaan yang sudah membudaya atau telah menjadi faktor setempat yang sama-sama tolong-menolong dan sama-sama bertanggung jawab atas pembangunan desa, kemasyarakatan dan pemerintahan serta memelihara keamanan bersama.

c. Ada organisasi pemerintahan sendiri, berarti bahwa orang-orang yang terhimpun pada satu unit organisasi itu dikenal langsung vleh masyarakat penduduk sebagai orang-orang yang dipercayakan dan memperoleh pelimpahan dari rakyat dan dilegalisir serta ditetapkan oleh pemerintah atasan.

Ada organisasi pemerintahan berarti ada susunan dan pembagian kerja terstruktur dan merupakan satu kesatuan terpadu dibawah kekepalaan dan pimpinan kepala desa dan bertanggung jawab vertikal dan horizontal.

d. Ada hak dan kewajiban (berhak dan berkewajiban) menyelenggarakan urusan rumah tangga sendiri berarti selalu dituntut adanya kreativitas sendiri, ada kemandirian yang timbul sebagai aspirasi dari bawah bagi penyelenggara urusan-urusan yang langsung menjadi kepentingan dan kebutuhan serta memberi manfaat kedalam desa sebagai manfaat rakyat desa secara keseluruhan.

Berarti juga ada kewenangan untuk menghimpun dana sendiri yang bersumber dari atas, bersama dengan aturan yang disusun sendiri dan berlaku setelah disahkan oleh pemerintah atasan.

Gerak mekanisme dari dalam sangat diutamakan demi untuk pembangunan kemasyarakatan dalam pembangunan. Hal ini sangat penting mengingat bahwa untuk membangun dan mengurus desa adalah menjadi tanggung jawab dari masyarakat desa itu sendiri bukan oleh desa lam.

Faktor kompetisi yang sehat siapa yang termaju, siapa yang terbaik dan boleh menjadi juara dalam hal-hal tertentu.

e. Dalam ikatan Negara Kesatuan Republik Indonesia berarti bahwa hal ini harus ditanamkan kepada masyarakat desa bahwa secara integral desa itu berada dalam ikatan negara bagaimanapun juga kecilnya atau bagaimanapun juga keadaan desa itu akan tetapi desa itu adalah bagian dari negara, miliknya negara Indonesia atau negara itu adalah negara dasi desa-desa, oleh karena negara Indonesia adalah negara yang terdiri atas desa-desa/kelurahan sebagai unit-unit pemerintahan terendah.

Desa sebagai unit pemerintahan terendah merupakan suatu yang unik dan spesifik karena desa menampakkan otonomi (berkekuasaan dan berpemerintahan sendiri), setempat dan melokal, yang mana seluruh anggota masyarakat dilibatkan pada urusan-urusan kebersamaan di desa seperti misalnya : 
- Bila ada orang meninggal, akan diurus secara bersama dengan adanya kebiasaan-kebiasaan yang ditaati oleh warga masyarakat.

- Dalam memelihara atau memperbaiki dan membuat jalan-jalan ke kebun secara rutin dikerjakan bersama.

- Di dalam menerima dan menyambut tamu-tamu dihadapi secara bersamasama dengan rasa hormat dan sopan santun kedesaan, demikian pun dengan acara-acara lainnya.

- Dalam menjaga keamanan, ketertiban intern desa dilakukan secara bersama-sama dengan anggaran-anggaran semuanya bersumber dari desa.

- Pembiayaan-pembiayaan intern dengan berdasarkan pada peraturan, semuanya diusahakan sebagai usaha gotong-royong dan swadaya masyarakat desa.

Dengan demikian dapat dikatakan bahwa menurut Undang-Undang Nomor 32 tahun 2004 desa dengan ciri-cirinya diperhatikan, dijunjung tinggi dan dihimbau untuk tetap dilestarikan.

Pembangunan desa merupakan konsep yang saat ini semakin banyak dikembangkan. Adapun pengertian pembangunan pada umumnya adalah usaha perubahan yang dilakukan secara sadar, berencana dan berkesinambungan menuju kearah yang lebih baik berdasarkan pada norma-norma tertentu, yang direncanakan dengan memberdayakan potensi alam, manusia dan sosial budaya (Beratha, 1982 : 32).

Konsep pembangunan merupakan bahasa dunia, dalam bahasa Inggris pembangunan disebut development. Beberapa istilah lain yang mengandung persamaan dengan development, misalnya modernisasi (modernization), pertumbuhan (growth), dan perubahan sosial (social change), bahkan juga rekonstruksi (reconstruction), dan pembangunan nasional (national building). Bertolak dari beberapa konsep pembangunan tersebut diatas maka pengertian pembangunan (development) yang dipakai dalam penulisan proposal ini yaitu pembangunan yang secara sadar dilaksanakan oleh suatu bangsa, negara dan pemerintah dalam rangka pembinaan bangsa (Siagian, 1985 : 15). Karena pembangunan merupakan amanat konstitusional dan merupakan cara satusatunya untuk mencapai tujuan negara Indonesia sebagaimana ditetapkan dalam UUD 1945.

Pengertian pembangunan tersebut merupakan salah satu tujuan negara Indonesia yang menyatakan bahwa pembangunan nasional merupakan upaya pembangunan yang berkesinambungan yang meliputi seluruh kehidupan masyarakat bangsa dan negara dalam mewujudkan tujuan nasional. Dengan demikian secara tegas diamanatkan kepada kita, bahwa sasaran utama dan bahkan tujuan akhir dari seluruh usaha pembangunan adalah manusia dan masyarakat. Hal ini merupakan acuan utama dari seluruh aparat dan perangkat serta masyarakat yang merupakan pemeran utama dalam proses pembangunan itu sendiri.

Di dalam konteks perubahan sosial, maka keberhasilan pembangunan manusia dan masyarakat tersebut menurut Direktur Pembinaan Ketahanan Masyarakat Desa (1992 : 25) menampilkan ciri-ciri antara lain ;

a. Terjadinya perubahan cara berpikir yang irasional menjadi berpikir rasional, yang selalu berusaha melihat dan memakai cara, metode ataupun sarana yang sesuai untuk mencapai tujuan tertentu. 
b. Perubahan dari cara berpikir tidak kritis menjadi berpikir kritis, yang menuntut adanya pengawasan melalui suatu manajemen terbuka. Berpikir kritis selalu mempertimbangkan semua unsur pro dan kontra, yang positif dan negatif, yang menghambat dan yang mendukung sesuatu rencana, juga mempertimbangkan secara mendalam adanya kemungkinan-kemungkinan atau alternatif.

c. Perubahan dari cara kerja yang tidak metodis menjadi metodis, yang berarti merencanakan kegiatan dengan teliti, melaksanakan dengan cara tertentu dan menilai hasilnya untuk perbaikan cara kerja berikutnya.

d. Perubahan cara berpikir yang berjangka panjang, yang berarti bukan hanya menentukan tujuan yang dicapai besok, melainkan untuk kurun waktu jauh ke depan.

e. Terwujudnya cara berpikir dan bertindak yang didasari oleh rasa tanggung jawab, yang akan menimbulkan kesadaran bahwa seseorang dapat mendorong atau menghambat pembangunan, juga akibat yang mungkin timbul dari tindakan dan langkahnya.

f. Perubahan cara berpikir dan bertindak yang feodalis menjadi demokratis, hak dan kewajiban pokok dari masyarakat pada dasarnya sama, semua pendapat di hormat dan kepentingan bersama diatas kepentingan pribadi.

\section{METODOLOGI PENELITIAN}

\subsection{Jenis Penelitian}

Jenis penelitian dalam penulisan ini, yaitu pendekatan "diskriptif-kualitatif". Metode kualitatif adalah suatu prosedur penelitian yang menghasilkan data diskriptif berupa kata-kata tertulis dari orang dan perilaku yang dapat diamati, Bogdan dan Taylor (1998) dalam Lexy J. Moleong (2005).

Penelitian ini diharapkan dapat memberikan gambaran secara nyata, komprehensif dan mendalam atas hasil penelitian pada obyek yang diteliti sesuai dengan tujuan penelitian. Dari penelitian yang dilaksanakan diharapkan dapat melengkapi bahan kajian bagi Pemda Kabupaten Gorontalo dalam mewujudkan sumber daya Aparatur Pemerintah Desa yang berkualitas sehingga mampu bekerja secara optimal dalam memberikan pelayanan kepada masyarakat, penyelenggaraan desa yang berdaya guna dan berhasil guna, serta dalam rangka penyelenggaraan otonomi desa.

\subsection{Lokasi Penelitian}

Dalam penelitian ini, lokasi yang dijadikan tempat penelitian yakni di Desa Ilotidea Kecamatan Tilango Kabupaten Gorontalo.

\subsection{Populasi dan Sampel}

Populasi adalah kumpulan objek penelitian (Rachman, 1999 : 75), sedangkan menurut P. Joko Subagja, SH (2004 : 22) Populasi adalah objek penelitian sebagai sasaran untuk mendapatkan dan mengumpulkan data, sehingga yang menjadi populasi penelitian adalah Perangkat Desa Ilotidea, Anggota BPD, Anggota Lembaga Pemberdayaan Masyarakat, dan toko-tokoh masyarakat, Kecamatan Tilango Kabupaten Gorontalo.

Sampel diambil secara acak, dengan menggunakan probability sampling, yaitu simple random sampling dengan cara pengambilan sampel dari semua anggota populasi dilakukan secara acak tanpa memperhatikan strata yang ada 
dalam anggota populasi itu (Sugiyono, 2001:59). Dalam penelitian sebagai pertimbangan efisiensi dan mengarah pada sentralisasi permasalahan dengan mengfokuskan pada sebagian dari populasi. Untuk memudahkan penelitian, maka dilakukan penarikan sampel yakni sebanyak 25 responden dari jumlah populasi sebanyak 50 .

\subsection{Variabel Penelitian Dan Definisi Operasional Variabel}

Variabel-variabel yang akan diteliti dalam penelitian ini terdiri dua variabel pokok yaitu :

1. Peningkatan kualitas perangkat pemerintah desa yang menjadi variabel bebas (independent) variabel yang mempengaruhi yang diberi simbol X.

2. Pemantapan pelaksanaan pembangunan di Desa Ilotidea Kecamatan Tilango Kabupaten Gorontalo sebagai variabel terikat atau variabel terpengaruh (dependent variable) yang diberi symbol Y.

Adapun kedua variabel tersebut diatas dapatlah didefinisikan sebagai berikut :

a. Untuk meningkatkan kualitas dari perangkat desa sebagai suatu kesatuan maka perlu program terpadu dan terarah dilakukan oleh pemerintah atasan dengan menempuh langkah-langkah, antara lain :

- Pemantapan tugas dan fungsi dari perangkat desa.

- Menciptakan kesatuan arah dan langkah dalam pelaksanaan tugas.

- Menciptakan iklim kerja yang kondusif (mendukung).

- Perlu adanya disiplin kerja dari seluruh perangkat pemerintah desa.

- Adanya kesejahteraan yang baik

Dengan demikian peningkatan kualitas perangkat desa akan nampak dan terwujud serta akan terciptanya efisiensi dan efektivitas kerja dalam pelaksanaan tugas dari seluruh perangkat pemerintah desa secara berkesinambungan.

b. Pemantapan pelaksanaan pembangunan di Desa Ilotidea didefinisikan dengan cara perwujudan dari kesatuan masyarakat untuk dapat berperan aktif secara nyata melalui keikutsertaan mereka di dalam menopang program-program pembangunan untuk pemantapan pelaksanaan pembangunan, oleh karena itu perlu dilakukan beberapa hal yaitu pertama, perlunya pemanfaatan seluruh potensi daerah Gorontalo dan memperkuat jaringan percepatan pembangunan pada tingkat nasional dan propinsi dan daya saing daerah ; kedua, perhatian yang serius dibutuhkan untuk sekitar pengembangan SDM dan penguatan "titik-titik kemajuan dan produktivitas masyarakat". Ketiga, dibutuhkan komitmen besar untuk percepatan pembangunan di Kecamatan Ilotidea dari semua unsur supaya pelaksanaan pembangunan dapat berjalan secara mantap.

\subsection{Instrumen Dan Teknik Pengumpulan Data}

Untuk memperoleh data primer dipakai alat bahwa kuisioner atau daftar pertanyaan yang disusun secara berstruktur dan dibantu dengan daftar pedoman wawancara atau interview guide, sedangkan untuk teknik penelitian documenter dan semua data yang diperoleh melalui teknik survey dan observasi langsung. 


\subsection{Teknik Analisa Data}

Analisa data yang digunakan dalam penelitian ini adalah analisis deskriptif kualitatif dengan persentase. Yaitu dengan cara mengumpulkan data dan dipisahkan menurut kategori untuk memperoleh kesimpulan dijumlahkan dibandingkan dengan jumlah yang diharapkan dan diperoleh presentase. Untuk itu menggunakan rumus presentase :

Di mana :

$$
\mathrm{P}=\frac{\mathrm{F}}{\mathrm{N}} \times 100 \%
$$

$$
\begin{aligned}
& \mathrm{P}=\text { Persentase yang dicari; } \\
& \mathrm{F}=\text { Frekuensi tiap kategori; } \\
& \mathrm{N}=\text { Besar sample responden (jumlah pengamatan) }
\end{aligned}
$$

\section{HASIL DAN PEMBAHASAN}

Perubahan mendasar dalam pengaturan desa adalah munculnya Badan Permusyawaratan Desa (BPD) yang merupakan lembaga tersendiri dan memiliki fungsi yang sangat luas. Pada tahun 1955 terbentuk lembaga desa yang berfungsi merencanakan segala kebutuhan desa bersama-sama dengan perangkat desa dengan sebutan Badan Perencanaan Pemerintah Desa (Bappensa). Nama ini berubah menjadi Badan Musyawarah Desa (Bamudes), berubah lagi menjadi Lembaga Musyawarah Desa (LMD) pada UU No 5/1979, lahirnya UU No 22/1999 berubah menjadi Badan Perwakilan Desa (BPD). Dalam UU No32/2004 dan UU No 12/2008 BPD menjadi Badan Permusyawaratan Desa (BPD). Perbedaan yang substansial antara LMD dan BPD ditinjau dari aspek fungsi dan Yuridis formal, yaitu LMD hanya memiliki fungsi legislasi, sementara BPD selain berfungsi legislasi juga berfungsi mengawasi pemerintah desa, dan juga menampung dan menyalurkan aspirasi masyarakat.

Pembahasan anggaran pendapatan dan belanja desa dimainkan oleh Badan Perwakilan Desa berdasarkan kemauan dan proses politik. Anggaran dana desa yang ada didesa dikelola secara otonomi oleh desa. Alokasi dana Desa sebagaimana UU No 6 Tahun 2014 didalam pasal 72 ayat (2) mengatur pula keuangan desa paling sedikit 10\% (sepuluh perseratus) dari dana perimbangan yang diterima Kabupaten/Kota dalam Anggaran Pendapatan dan Belanja Daerah setelah dikurangi Dana Alokasi Khusus. Selain potensi keuangan juga terdapat potensi sumber daya alam, seperti tambang galian c, pariwisata, air bersih dan pertanian. Oleh karena itu penguatan fungsi aparat desa dalam mengelola APBDes merupakan langkah strategis yang perlu dilakukan.

Penyusunan APBDes mengatur alokasi belanja pemerintah desa lebih banyak digunakan untuk menggerakkan pemerintah desa daripada digunakan pada masyarakat desa. Ini menunjukkan bahwa bahwa penggunaan dana desa belum dapat memecahkan masalah-masalah kemiskinan, infrastruktur, peningkatan pendidikan dan kesehatan. Padahal APBDes dapat dimanfaatkan untuk menciptakan kesejahteraan masyarakat. Diperlukan upaya BPD untuk mengatur anggaran dengan baik sehingga penggunaan anggaran efektif dan efisiensi.

Proses pemerintah Desa Ilotidea Kecamatan Tilango Kabupaten Gorontalo memiliki suatu peran yang dilakukan oleh aparat desa guna pemantapan dalam pembangunan desa. Salah satu tugas aparat desa adalah sebgai kepala urusan pemerintahan memiliki tugas yaitu Membantu Kepala desa untuk melakukan 
pengelolaan administrasi kependudukan, administrasi pertanahan, pembinaan, ketertiban masyarakat suatu desa, persiapan bahan dalam pelaksanaan kebijakan seperti kebijakan penataan dan kebijakan hukum desa. Sementara itu, fungsi pokok kepala urusan umum yaitu melaksanakan administrasi kependudukan, mempersiapkan bahan untuk menyusun rancangan peraturan serta keputusan kepala desa, melaksanakan administrasi pertanahan, mencatatat monografi desa, mempersiapkan bantuan yang bertujuan untuk memperlancar penyelenggaraan dalam pemeritahan di desa dan melakukan penataan kelembagaan masyarakat, dan melakukan tugas lain yang diberikan atau diperintahkan oleh kepala desa.

Tugas dan fungsi pemerintah dalam demikian luas dan kompleks yaitu meliputi seluruh aspek kehidupan masyarakat. Desa merupakan kesatuan masyarakat hukum yang memiliki kewenangan untuk mengatur dan mengurus kepentingan masyarakat setempat berdasarkan asal usul dan adat istiadat setempat. Kajian politik pada pasal 18 UUD 1945 mencerminkan pengakuan negara terhadap otonomi desa. Desa sebagai susunan asli memiliki hak asal usul dan hak otonom. Adapun daerah-daerah besar dan kecil lainya, semacam provinsi, kabupaten ataupun kota yang dikenal dalam sistem pemerintahan bersifat otonom karena pemberian pusat terhadap hak otonom bagi daerahdaerah tersebut. Otonomi daerah ini sebagai konsekuensi desentralisasi di Indonesia.

Menurut kepala desa Desa Ilotidea Kecamatan Tilango Kabupaten Gorontalo menyatakan bahwa peran seluruh kepala urusan pemerintahan dalam administrasi pemerintahan belum berjalan secara optimal. Karena peranan itu belum bisa secara mandiri dilaksanakan, apakah itu terkait dengan administrasi kependudukan, administrasi pertanahan, dan lain-lain. Semua tugas tersebut selalu dikomunikasikan kepada saya selaku kepala desa sehingga semua urusan kepala urusan pemerintahan menjadi tanggung jawab saya. Padahal begitu banyak urusan yang harusnya diselesaikan namun karena keterbatasan kaur pemerintahan terpaksa harus dibantu terlebih dahulu. Oleh karena itu kemampuan yang optimal dibutuhkan dalam rangka untuk melakukan pembangunan di Desa Ilotidea Kecamatan Tilango Kabupaten Gorontalo.

Sementara itu, Tugas aparat desa sebagai Kepala Urusan Pembangunan yaitu membantu kepala desa dalam mempersiapkan bahan untuk perumusan kebijakan teknis dalam hal pengembangunan potensi desa, Mengelola administrasi pembangunan, Mengelola pelayanan masyarakat. Fungsi kepala urusan pembangunan yaitu sebagai pelaksana dalam kegiatan administrasi pembangunan; mempersipakan bantuan untuk kajian perkembangan ekonomi warga masyarakat; dan Melakukan tugas lain yang diberika atau diperintahkan oleh kepala desa. Dalam hal ini menunjukkan bahwa kepala urusan pemerintahan belum dapat optimal melaksanakan tugasnya dengan baik. Hal itu akibat karena sumber daya yang dimilikinya masih sangat terbatas dan masih berada dalam proses pembelajaran. Oleh karena itu kepala urusan pembangunan belum dapat membantu kepala desa dalam mempersiapkan perumusan kebijakan teknis, seperti penbangan potensi desa, mengelola administrasi pembangunan, dan juga memberikan pelayanan prima kepada masarakat. Keterbatasan aparat desa terbukti dengan adanya kepala urusan pembangunan yang belum bergerak mandiri dalam proses yang berkaitan langsung dengan tugas dan fungsinya. Oleh karena itu perlu ada penataan 
dalam bentuk program pendidikan dan pelatihan kepada aparat desa, sehingga dapat mengatasi kekurangan yang ada pada aparat desa. Kemampuan aparat desa sangat penting dalam mendorong pelaksanaan administrasi pemerintahan desa di Desa Ilotidea Kecamatan Tilango Kabupaten Gorontalo.

Hasil wawancara tersebut menunjukkan bahwa peran aparat desa di desa Ilotidea masih kurang maksimal. Karena kepala urusan umum kurang mampu dalam melaksanakan tugas dan perannya melainkan lebih dimonopoli oleh sekretaris desa Ilotidea. Dengan keadaan di desa tersebut diharapkan agar peran masing-masing bagian dalam organisasi pemerintahan desa dapat berjalan maksimal agar kinerja aparat dalam pembangunan desa berjalan efektif. Pencatatan atau register adalah suatu aktivitas pemerintahan dengan maksud untuk mendokumentasikan berbagai peristiwa dan atau kegiatan yang telah terjadi melalui pencatatan-pencatatan di dalam format yang telah ditetapkan. Daftar register dalam penyelenggaraan pemerintahan pada tingkat dalam hingga sekarang ini yang digunakan di Desa Karyamukti adalah berdasarkan pada Kepmendagri Nomor 414.3/316/PMD/2003, tentang Register Dalam. Dalam Keputusan tersebut, ditetapkan adanya tiga jenis buku yang terdiri dari Buku Administrasi Umum, meliputi Buku Kekayaan dan inventaris dalam, buku tanah, buku keputusan dalam dan buku agenda; Buku Administrasi Penduduk, meliputi Buku Induk Penduduk dan Buku Rekapitulasi Penduduk Akhir Bulan, dan Buku Administrasi Keuangan meliputi Buku Kas Umum dan Buku Kas Pembantu.

Kemampuan aparat desa di Desa Ilotidea Kecamatan Tilango Kabupaten Gorontalo didalam mempersipakan perumusan kebijakan yang sudah ada draftnya saya pribadi bisa. Akan tetapi membantu kepala desa dalam mempersiapkan bahan untuk perumusan kebijakan teknis dalam hal pengembangunan potensi desa, mengelola administrasi pembangunan, dan mengelola pelayanan masyarakat belum dapat maksimal apabila dikerjakan sendiri. Hal tersebut menunjukkan bahwa kemampuan aparat desa masih terbatas dalam melaksanakan tugas dan fungsinya. Selain kepala urusan pembangunan juga masih terdapat Tugas aparat desa sebaga Kepala Urusan Umum yaitu membantu sekretaris desa dalam melaksanakan tugas administrasi umum, kearsipan, tata usaha, inventaris desa, dan menyiapkan segala bahan untuk rapat dan pembuatan laporan. Adapun fungsi kepala urusan umu yaitu Pengendalian kearsipan dan surat masuk serta surat keluar, mencatat inventaris atau kekayaan desa, Melakukan tugas administrasi umum, Menyimpan, menyediakan, dan menyalurkan alat-alat tulis kantor serta bertanggungjawab dalam memelihara dan perbaikan terhadap perabot atau perlengkapan kantor, melaksanakan pengelolaan administrasi perangkat desa, menyiapkan bahan untuk membuat laporan, dan melakukan tugas lain yang diperintahkan oleh sekretaris desa.

Berdasarkan hasil penelitian menunjukkan bahwa pelaksanaan tugas pemerintahan Desa di Desa Ilotidea Kecamatan Tilango Kabupaten Gorontalo dalam pencatatan atau pengisian Buku-buku register tersebut, dapat dinilai tidak efektif. Hal tersebut terlihat dari sembilan buku register yang harus diisi oleh perangkat desa, ternyata yang terisi hanya 5 buku, yaitu: Buku Agenda, Buku Aparat, Buku Keputusan Dalam, Buku Induk Penduduk dan Buku Kas Pembantu. 
Lebih lanjut dapat dijelaskan bahwa buku yang terisi tersebut, data atau informasinya tidak akurat dan tidak lengkap. Rincian tentang ketidaklengkapan pengisian buku-buku tersebut, diantaranya pertama, buku agenda adalah buku tentang pencatatan surat-surat masuk dan keluar. Dalam penelitian ini tercatat 14 surat masuk dan 8 surat keluar. Dan penelitian yang dilakukan pada buku agenda terlihat bahwa 10 kolom yang tersedia pada agenda surat masuk ternyata kolom 5, 6, 7, 10 yaitu : nama instansi yang mengirim, penanggung jawab pengelola dan kolom keterangan tidak terisi. Kedua, buku aparat adalah buku tempat pencatatan berbagai informasi tentang keadaan aparat pemerintah dalam. Dari 11 kolom yang tersedia, ternyata yang terisi hanya 6 kolom, sedangkan yang tidak terisi sebanyak 5 kolom, yaitu ; kolom NIP, Tempat dan tanggal lahir, Pangkat/Golongan, Tanggal Keputusan Pengangkatan dan kolom keterangan.

Aspek Ketiga, buku keputusan dalam adalah buku tempat mencatat data/informasi mengenai, kebijakan atau keputusan pemerintah dalam, sehubungan dengan penyelenggaraan pemerintahan dan pembangunan di tingkat dalam. Keempat, Buku Induk Penduduk adalah buku tempat mencatat seluruh penduduk yang menjadi warga di dalam tersebut, serta berbagai karakteristik yang melingkupi, setiap individu warga tersebut. Kelima, Buku Kas Umum adalah buku tempat pencatatan setiap kegiatan penerimaan rutin dan pembangunan serta pengeluaran dan pembangunan setiap hari. Buku Kas umum berfungsi untuk mengetahui berapa jumlah penerimaan dan pengeluaran setiap hari terhadap keadaan uang tunai yang ada pada kas dalam.

Pembuatan dan pencatatan Monografi merupakan salah satu tugas dari perangkat desa. Tugas tersebut perlu dilaksanakan dan untuk selanjutnya ditampilkan dalam ruang kantor. Hal ini penting mengingat papan monografi tersebut dapat memberikan informasi dan data kepada pihak luar atau masyarakat umum tentang keadaan Wilayah dengan berbagai potensinya. Namun pada kunjungan kekantor desa tidak ada peneliti temukan. Penyimpanan dokumen-dokumen atau arsip secara baik adalah salah satu tugas perangkat desa. Dengan penyimpanan arsip yang baik dapat membantu aparat desa upaya menemukan kembali, jika data itu dibutuhkan untuk suatu kepentingan. Namun dari kaji dokumen dan pengamatan penulis, ternyata tugas tersebut tidak dilaksanakan dengan baik. Hal ini terbukti dengan tidak ditemukannya arsip dan atau register-register yang tidak dipaparkan sebelumnya pada kantor. Akan tetapi daftar register dimaksud tersimpan dan atau berserakan di rumah Kepala desa.

Berdasarkan seluruh uraian sebelumnya, khususnya uraian tentang kondisi rill pelaksanaan, tugas perangkat desa dalam arti sempit, yang meliputi : pencatatan register, pembuatan dan pencatatan monografi dalam, dan penyimpanan dokumen/arsip, diperoleh gambaran bahwa pelaksanaan tugas aparat desa dapat dinilai kurang efektif. Hal tersebut terlihat dari tidak akuratnya data dan atau informasi yang diuraikan dan tidak terealisasinya seluruh tugas dan fungsi yang menjadi tugas dan fungsi masing-masing aparat desa. Bahkan data-data atau informasi yang dipaparkan tidak "op to date" lagi, karena data/informasi yang berlangsung adalah data/informasi yang belangsung beberapa tahun sebelumnya yaitu data antara tahun 2008 hingga tahun 2012. 
Tidak efektifnya pelaksanaan tugas perangkat desa dapat diketahui melalui aktifitas kearsipan atau penyimpanan dokumen yang tidak efektif, bahkan cenderung gagal dilaksanakan sebagaimana mestinya. Maksudnya adalah bahwa arsip-arsip surat-menyurat yang harusnya disusun dan tersimpan pada kantor tetapi hal itu tidak dilakukan. Akan tetapi dokumen/arsip Surat-Surat dimaksud tidak disimpan rapi (berserakan), sehingga sangat sulit untuk menemukannya kembali bila dibutuhkan. Selain itu, dari pengamatan peneliti selama melakukan penelitian terlihat bahwa aparat atau perangkat desa kurang efektif dalam melaksanakan tugas sehari-hari, bahkan cenderung tidak efektif ditinjau dari aspek disiplin waktu. Hal ini terlihat dari kehadiran aparat pada setiap hari kerja sangat terbatas, bahkan sering terjadi seorang aparat tidak masuk kantor selama satu minggu. Bahkan kadangkala pada hari-hari tertentu kantor tidak terbuka karena aparat tidak ada yang hadir. Akibatnya sering terjadi pelayanan pada masyarakat dilakukan di rumah aparat, terutama di rumah Kepala Desa atau Sekretaris Desa. Keadaan tersebut, semakin memperjelas, bahwa pelaksanaan tugas perangkat desa dalam urusan administrasi pemerintahan desa masih tidak efektif. Dari beberapa uraian tersebut diatas, maka dapat ditarik suatu kesimpulan bahwa Peranan Aparat Desa dalam pelaksanaan tugas administrasi pemerintahan di Desa Karyamukti Kecanatan Mootilango kabupaten Gorontalo masih kurang maksimal. Penilaian tersebut karena dari tiga kepala urusan, baik pemerintahan, pembangunan, dan umum mengakui bahwa perannya belum maksimal dalam melakasanakan tugas dan fungsinya secara efektif.

\section{PENUTUP}

Dalam penelitian tentang Peningkatan Kualitas Perangkat Desa Guna Pemantapan Pelaksanaan Pembangunan Di Desa Ilotidea Kecamatan Tilango Kabupaten Gorontalo didapat suatu hasil penelitian yaitu: Pertama, Kualitas perangkat desa masih belum optimal atau masih sangat perlu untuk ditingkatkan. Kedua, Kemampuan, kemauan dan potensi perangkat desa serta dampak-dampak dan pendekatan pemerintahan dan pelaksanaan pembangunan belum maksimal karena sumber daya manusia masih terbatas.

Disarankan agar dalam penelitian tentang Peningkatan Kualitas Perangkat Desa Guna Pemantapan Pelaksanaan Pembangunan Di Desa Ilotidea Kecamatan Tilango Kabupaten Gorontalo dilakukan suatu upaya pemerintah daerah kabupaten Gorontalo dalam meningkatkan upaya pembangunan kemampuan aparatur desa di Desa Ilotidea Kecamatan Tilango Kabupaten Gorontalo

\section{DAFTAR PUSTAKA}

Anwar Ardiwilaga. 1985, Pemerintahan Desa. Tarsito Bandung.

Beratha I Nyoman. 1982. Desa, Masyarakat Desa dan Pembangunan Desa. Ghalia Indonesia, Jakarta.

Bintarto R. 1983. Interaksi Desa, Kota dan Permasalahannya. Ghalia Indonesia, Jakarta.

Bryant, Coratie dan White, Louisse. G. 1989. Manajemen Pembangunan Untuk Negara Berkembang (Managing Development in the Third Word). 
Penerjemah : Rusyanto, L. Simatupang. Cetakan Kedua. Jakarta : LP3ES Kerjasama dengan USAID.

C.S.T. Kansil, SH. Drs. 1479. Pokok-Pokok Pemerintahan di Daerah. Aksara Baru, Jakarta.

Depdikbud. 1990. Kamus Besar Bahasa Indonesia. Balai Pustaka Jakarta.

Kamaludin Rustian. 19\$1. Beberapa Aspek Pembangunan Nasional dan Daerah. Ghalia Bandung.

Kartohadikoesoemo Soetardjo. 1975. Desa. Sumur Bandung.

Kartasasmita, Ginandjar. 1996. Pembangunan Untuk Rakyat (Memadukan Pertumbuhan dan Pemerataan), Cetakan Pertama, Jakarta : PT. Pustaka Cidesindo.

Khairudin H. Drs., 1992. Pembangunan Masyarakat. Liberty Yogyakarta.

Kusnady, Ir. 1995. Membangun Desa. Penebar Swadaya, Jakarta.

Lisen, 1964. Individu Masyarakat. Sumur, Bandung.

Siswanto Joko, 1988. Administrasi Pemerintahan Desa. CV. Armico, Bandung.

Sondang P. Siagian. 1983. Sistem Informasi Untuk Pengambilan Keputusan. Gunung Agung, Jakarta.

, 1985. Administrasi Pembangunan. Cetakan kesebelas. Jakarta : Gunung Agung.

Sugiyono. 2001. Metode Penelitian Administrasi. Alfabeta, Bandung.

Surianingrat, Bayu, Drs. 1992. Pembangunan Administrasi Desa dan Kelurahan. Rineka Cipta, Cetakan Keempat, Jakarta.

Suwignjo, Drs. 1986. Administrasi Pembangunan Desa dan Sumber-sumber Pendapatan Desa. Ghalia Indonesia, Jakarta.

Subagjo Joko, P. SH. 2004. Metode Penelitian. Cetakan Keempat Rineka Cipta, Jakarta.

Tampi A. L.. 1983. Meningkatkan Kualitas Manusia Indonesia dalam Pembangunan. Bahan Seminar Nasional.

Tilaar H.A.R. 1993. Pengembangan Sumber Daya Manusia Yang Berbudaya dalam Pembangunan Jangka Panjang Kedua. Lembaga Pengembangan Manajemen Pendidikan IKIP Jakarta.

Westra Pariata, dkk. 1981 Ensiklopedi Administrasi. Gunung Agung, Jakarta. 